\title{
ANALISIS HUBUNGAN POLITIK DAN DUKUNGAN ORGANISASIONAL DENGAN SIKAP KERJA, KINERJA, DAN PERILAKU CITIZENSHIP ORGANISASIONAL
}

\author{
Fenika Wulani \\ Unika Widya Mandala Surabaya
}

\begin{abstract}
This study examined relationship of organizational politics and support to job satisfaction, turnover intent, organizational commitment (affective dan normative), job performance and OCB; and to investigated whether politics could explained incremental variance in dependent variable beyond be explained by support, or vice versa. The sample was accountant staff those working at 15 Public Accountant Offices in Surabaya. The result show that politics were negatively related to job satisfaction, affective and normative commitment, job performance; positively related to turnover intent. Support was positively related to job satisfaction, affective and normative commitment; negatively related to turnover intent. Politics and support could explained incremental variance beyond each other.
\end{abstract}

Keywords: organizational politics, job performance, politics support

\section{PENDAHULUAN}

Kerja yang dilakukan individu merupakan suatu investasi (Cropanzano et al., 1997), karena mereka harus memberikan waktu, tenaga, dan usahanya (Randall et al., 1999) untuk memperoleh apa yang mereka inginkan, seperti keuntungan ekonomi, fellowship, dan status sosial (Cropanzan et al., 1995; pada Randall et al., 1999). Di lain pihak, perusahaan tempat mereka ber'investasi', dihadapkan pada tekanan lingkungan ekonomi yang selalu berubah. Hal ini mengharuskan perusahaan untuk terus-menerus meningkatkan kinerja melalui penurunan biaya, inovasi produk dan proses, peningkatan mutu, produktivitas, dan kecepatan (Becker \& Gerhart, 1996; Roome, 1994). Untuk itu, perusahaan akan memberikan reward kepada pekerjanya agar mereka dapat bekerja seperti yang diinginkan. Dengan demikian pada tempat kerja terjadi suatu transaksi berupa pertukaran sosial (Randall et al., 1999).

Pekerja dengan kinerja baik mendapat jaminan pekerjaan dari perusahaan, yang akan membantu pekerjanya merencanakan karir mereka dan menyediakan promosi sebagai jaminan pengembangan karirnya; sebaliknya, pekerja akan berkomitmen dan loyal terhadap perusahaan (Cavanaugh \& Noe, 1999). Reward juga akan menghasilkan kepuasan kerja (Heskett et al., 1994). Settoon et al. (1996) menyatakan bahwa dalam pertukaran ini terdapat Organizational Citizenship Behavior (OCB) sebagai kontribusi pekerja pada perusahaan.

Namun demikian, Cropanzano et al. (1997) menyatakan bahwa ada dua konstruk yang menjelaskan karakteristik suatu social marketplace, yaitu politik dan dukungan. Ketika marketplace itu bersifat politik, individu-individu mencapai keinginannya dengan bersaing dan memperbesar power, sehingga investasi pekerja menjadi berisiko. Individu mungkin tidak mendapat jaminan imbalan yang tinggi dan mereka akan mengurangi alokasi sumberdayanya pada organisasi. Ketika marketplace-nya mendukung, perusahaan membantu memenuhi kebutuhan pihak lain. Di sini individu dapat berharap memperoleh imbalan lebih baik dan lebih yakin bahwa investasi mereka akan menguntungkan. Berdasarkan studi-studi terdahulu ditemukan bahwa politik dan dukungan organisasional berhubungan dengan sikap kerja, kinerja dan OCB (Randall et al.,1999; Van Dyne Graham, \& Dienesch, 1994)

Perilaku politik merupakan perilaku yang secara organisasional tidak ada sanksinya, yang mungkin dapat merugikan bagi tujuan organisasional atau bagi kepentingan orang lain dalam organisasi (Harrell-Cook 
et al., 1999). Evaluasi subyektif individu terhadap situasi atau perilaku yang diobservasi sebagai politik merupakan politik organisasional yang dipersepsikan (Harrell-Cook et al., 1999). Politik organisasional ini telah menjadi topik khusus dalam literatur manajemen (Maslyn \& Fedor, 1998) dan diminati secara khusus oleh para peneliti karena tantangan potensial yang diberikan bagi keefektifan dan efisiensi organisasi. Misalnya saja, pekerja yang mempersepsikan bahwa politik organisasional telah mencurangi mereka sehingga mereka kehilangan kesempatan yang diinginkan, maka mereka akan menunjukkan reaksi negatif seperti ketidakpuasan, kecemasan, kelesuan, dan turnover (Kacmar et al., 1999).

Keyakinan yang dibentuk pekerja terhadap sejauh mana perusahaan menilai kontribusi mereka dan memperhatikan kesejahteraan mereka merupakan dukungan organisasional yang dipersepsikan (Eisenberger et al., 1986). Selain itu, persepsi terhadap dukungan organisasional juga diperoleh melalui berbagai keputusan sumberdaya manusia, seperti promosi dan seleksi (Sheridan et al., 1990; pada Wayne et al., 1997) yang memiliki kaitan dengan sikap kerja, kinerja, dan OCB.

Seperti yang dinyatakan Randall et al. (1999), dalam studi-studi terdahulu pengujian hanya dilakukan untuk menguji salah satu dari kedua konstruk tersebut, hanya sedikit yang menguji apakah politik dan dukungan menjadi prediktor kegiatan kerja nyata seperti kinerja dan OCB. selain itu masih ada beberapa pertentangan hasil antara studi-studi terdahulu (tabel 1). Penelitian ini merupakan replikasi studi Randall et al. (1999), yang menguji apakah politik dan dukungan organisasional yang dipersepsikan berhubungan dengan komitmen afektif dan continuance, kepuasan kerja, turnover intent, kinerja dan OCB; dan apakah politik dapat menjelaskan varians inkremental dalam variabel dependen melebihi yang dijelaskan dukungan, atau sebaliknya. Studi ini juga dikembangkan untuk menguji hubungan politik dan dukungan dengan komitmen normatif, dengan menggunakan sampel yang berbeda, yaitu pada perusahaan jasa profesional (akuntan publik yang bekerja pada Kantor Akuntan Publik).

\section{KERANGKA TEORITIS DAN PENGEMBANGAN HIPOTESIS}

\subsection{Sikap dan perilaku}

Politik dan dukungan organisasional ada pada marketplace, dimana pertukaran sosial terjadi. Blau (1964; pada Settoon et al., 1996) menyatakan bahwa konsep pertukaran sosial ini telah lama digunakan oleh peneliti organisasional untuk menjelaskan motivasi yang mendasari sikap dan perilaku pekerja. Gibson et al. (1997) menyatakan bahwa ada dua pengaruh utama pada sikap, (1) pengalaman kerja, misalnya mengenai kesamaan gaji, penilaian kinerja, kemampuan manajerial, disain kerja, dan afiliasi kelompok kerja; dan (2) pembelajaran dalam masyarakat. Dalam penelitian ini, lebih difokuskan pada pengaruh yang pertama, yaitu pengalaman kerja, yang dapat membentuk persepsi individu terhadap sesuatu (Gibson et al., 1997). Karena dalam proses transaksi terdapat sifat politik dan dukungan organisasional, pengalaman terhadap keduanya akan membentuk persepsi mengenai ada tidaknya sifat ini.

Perilaku diprediksi oleh sikap (Luthans, 1995). Settoon, et al. (1996) menggunakan kinerja in role dan extra role (OCB) sebagai variabel perilaku. Sedangkan Gibson et al. (1997) mengkonsepkan kinerja sebagai outcomes perilaku. Dalam penelitian ini, digunakan konsep Randall et al. (1999) yang menyebut "apa yang dirasakan orang mengenai pekerjaannya", sebagai sikap kerja (komitmen, kepuasan kerja, dan turnover intent), kinerja dan OCB disebutnya sebagai 'bagaimana orang bertingkah laku dalam bekerja".

\subsection{Politik organisasional}

Politik merupakan realita kehidupan organisasional, karena dalam banyak organisasi pertimbangan politik hampir selalu menjadi bagian dalam proses evaluasi, dibanding pertimbangan rasional (Longenecker et al., 1987). Dalam model rasional, pengambilan keputusan dilakukan dengan memilih alternatif tindakan yang bernilai maksimum, masuk akal dan sesuai dengan tujuan. Sedangkan dalam model politik, pengambilan keputusan dan tindakan ditentukan melalui proses konflik, memberlakukan power dan membangun konsensus. Kepentingan individu dan kelompok membangun penghalang melalui proses politik (Allison, 1971; pada Drory, 1993). Dalam beberapa penelitian ditemukan pula bahwa politik organisasional berhubungan dengan kesempatan promosi atau peningkatan karir (Ferris \& Kacmar, 1992), dan proses penilaian kinerja (Longnecker et al., 1987). 
Pfeffer (1992; pada Greenberg \& Baron, 1997) mengemukakan beberapa aspek situasi yang dapat memunculkan aktivitas politik:

1. Perilaku politik biasanya muncul pada saat ada ketidakpastian, sumberdaya yang langka, unit-unit (individual dan kelompok) memiliki kepentingan yang berkonflik, dan saat anggota-anggota organisasi memiliki power yang hampir sama.

2. Politik dalam manajemen sumberdaya manusia. Perilaku politik seringkali berpusat pada aktivitas kunci manajemen sumberdaya manusia seperti penilaian kinerja, seleksi personel, dan keputusan kompensasi (Ferris \& Kacmar, 1992). Hal ini kemungkinan karena adanya ambiguity. Lingkungan organisasional bersifat ambiguous karena tidak adanya kriteria evaluasi yang jelas, sehingga organisasi cenderung kurang bergantung pada hasil yang dapat diukur dan lebih pada usaha pekerja, potensi yang dipersepsikan, dan karakteristik, nilai, dan sikap personal. Semua hal tersebut dapat diubah melalui manipulasi pertimbangan (Ferris \& King, 1991).

Politik organisasional telah didefinisikan dalam berbagai cara seperti Pfeffer (1981; pada Randall et al., 1999) yang menyatakan bahwa politik organisasional adalah 'studi mengenai penerapan power'. Sedangkan Nelson dan Quick (1997) mendefinisikannya sebagai penggunaan power dan pengaruhnya dalam organisasi. Dalam bidang riset, politik organisasional dikonstrukkan sebagai persepsi, seperti yang dikutip oleh Ferris dan Kacmar (1992) dari berbagai studi, misalnya Gandz dan Murray (1980) pada Ferris dan Kacmar (1992) yang menyatakan bahwa politik organisasional merupakan suatu pengalaman subyektif dan oleh karenanya ia akan menetap di pikiran. Sebelumnya, Porter (1976; pada Ferris \& Kacmar, 1992) menyatakan bahwa persepsi penting untuk mempelajari dan memahami meskipun mereka misperseption terhadap event aktual, khususnya yang mengarah pada politik organisasional. Mengacu pada Ferris, Russ, dan Fandt (1989; pada Kacmar et al., 1999), Perception of Organizational Politics (POP) akan mempengaruhi individual dan hasil organisasional seperti intensi untuk keluar, absen, kecemasan kerja, keterlibatan kerja, dan kepuasan kerja.

\subsubsection{Politik organisasional dan kepuasan kerja}

Greenberg dan Baron (1997) menyatakan bahwa salah satu cara meningkatkan kepuasan kerja adalah pemberian gaji secara fair, dan Luthans (1995) menyatakan bahwa kepuasan kerja dipengaruhi promosi dan gaji, yang merupakan keputusan sumberdaya manusia. Sedangkan politik organisasional sangat berhubungan dengan area pengambilan keputusan. Keputusan organisasional tersebut mungkin dipersepsikan sebagai pencerminan prinsip ke-fair-an, rasional, keprofesionalan. Pada kenyataannya, dalam pengambilan keputusan tersebut terdapat unsur kepentingan diri sendiri atau kelompok, dan permainan power yang tidak adil (Drory, 1993). Dengan demikian, dapat dikatakan bahwa jika pekerja mempersepsikan ada politik dalam organisasi, maka kepuasan kerjanya akan turun. Beberapa penelitian telah menemukan bahwa kepuasan kerja dipengaruhi dan berhubungan negatif dengan politik organisasional (Ferris, Russ, dan Fandt, 1989; pada Kacmar et al., 1999; Cropanzano et al., 1997; Randall et al.,1999)

Hipotesis:

H1a. Politik berhubungan secara negatif dengan kepuasan kerja

\subsubsection{Politik organisasional dan turnover intent}

Mengacu pada Frost (1987; pada Kacmar et al., 1999), pekerja akan mengundurkan diri dari organisasi untuk menghindari aktivitas politik. Salah satu bentuknya adalah turnover, baik dalam bentuk aktual maupun psikologis (intensi). Menurut kacmar et al. (1999), psikologis turnover ini meliputi pemikiran untuk keluar seperti yang dibicarakan dengan orang lain. Dari hasil penelitiannya, ditemukan bahwa intensi untuk keluar ini berhubungan positif dengan politik organisasional yang dipersepsikan.

Hipotesis:

H1b. Politik berhubungan secara positif dengan intensi untuk keluar 


\subsubsection{Politik organisasional dan komitmen organisasional}

Saat pekerja merasa dihambat dan diperlakukan tidak fair karena pertimbangan politik, maka ia akan mengurangi kewajiban dan keterikatannya dengan organisasi. Komitmen organisasional merupakan bentuk yang sangat relevan terkena dampak kekecewaan pekerja terhadap organisasi (Drory, 1993). Komitmen afektif berkaitan dengan kesesuaian antara nilai dan gol individu dengan organisasi (Allen \& Meyer, 1990), sehingga pekerja akan membentuk ikatan dengan organisasi yang nonpolitik, karena dengan demikian organisasi dalam jangka panjang akan memenuhi kebutuhan mereka (Randall et al., 1999). Maslyn dan Fedor (1998) yang mengukur komitmen organisasional dengan menggunakan item skala komitmen afektif, menemukan bahwa komitmen organisasional signifikan berhubungan negatif dengan politik organisasional yang dipersepsikan. Hasil yang sama ditemukan dalam penelitian Randall et al. (1999)

Karena komitmen continuance secara kuat dipengaruhi oleh hal yang berkaitan dengan ekonomi, studi Randall et al. (1999) menemukan bahwa tidak ada hubungan antara politik dan komitmen continuance. Penulis memprediksi tidak ada hubungan antara komitmen normatif dengan politik organisasional karena komitmen normatif menekankan kewajiban untuk loyal berkaitan dengan benefit yang telah diberikan oleh perusahaan.

\section{Hipotesis:}

H1c. Politik berhubungan secara negatif dengan komitmen afektif

\subsubsection{Politik organisasional dan kinerja-OCB}

Randall et al. (1999) menyatakan bahwa karena lingkungan politik mengarah pada investasi yang berisiko, maka pekerja akan berusaha untuk mengkontribusikan sedikit usahanya bagi organisasi, sehingga akan mengarah pada penurunan kinerja dan OCB. Semakin lingkungan kerja bersifat politik, semakin berkurang citizenship (Maslyn \& Fedor, 1998). Maslyn dan Fedor (1998) menemukan bahwa politik organisasional yang dipersepsikan berhubungan secara negatif dengan OCB. Kacmar et al. (1999) menyatakan bahwa persepsi politik berdampak pada tidak termotivasinya individu sehingga terjadi penurunan tingkat kinerja. Kacmar et al. (1999) juga menemukan hubungan negatif antara persepsi politik organisasional dengan kinerja.

\section{Hipotesis:}

H1d. Politik berhubungan secara negatif dengan kinerja

H1e. Politik berhubungan secara negatif dengan OCB

\subsection{Dukungan Organizational}

Blau (1964; pada Settoon et al., 1996) menyatakan bahwa dasar hubungan pertukaran dapat dijelaskan dalam terms prinsip sosial atau ekonomi. Pertukaran benefit khusus akan dihargai tinggi karena hal itu merupakan simbol hubungan yang berkualitas tinggi; yaitu pertukaran dukungan timbal balik dari orangorang yang terlibat dalam pertukaran. Ada dua cara utama pertukaran sosial, yaitu hubungan pertukaran global antara pekerja dan organisasi, dan hubungan dyadic antara atasan dan bawahan (Settoon et al., 1996).

Dalam hubungan pertukaran global, pekerja mempertimbangkan organisasi menjadi suatu keseluruhan, bukan individual, dengan siapa mereka memiliki hubungan pertukaran (Rousseau, 1990; Shore \& Tetrick, 1994; pada Wayne et al., 1997). Keyakinan global mengenai sejauh mana organisasi menilai kontribusi, memperhatikan kesejahteraan, mendengar keluhan, memperhatikan kehidupan, mempertimbangkan gol dan nilai-nilai, dan dapat dipercaya untuk memperlakukan mereka dengan fair; merupakan dukungan organisasional yang dipersepsikan (Perceived Organizational Support/POS). Ditambahkan oleh Van Dyne et al. (1994) bahwa POS berkorelasi dengan perilaku pekerja. 


\subsubsection{Dukungan organisasional dan kepuasan kerja.}

Dalam POS terdapat unsur ke-fair-an, penghargaan, perhatian terhadap kehidupan pekerja, dan mempertimbangkan gol dan nilai-nilai pekerjanya (Eisenberger et al., 1986). Karena kepuasan kerja merupakan bentuk emosional yang mencerminkan respon terhadap situasi kerja, penilaian kerja, atau pengalaman kerja (Locke,1976; pada Brooke, Jr. et al., 1988), maka persepsi pekerja terhadap dukungan organisasional akan berpengaruh pada kepuasan kerja ini. Beberapa studi menemukan hubungan positif antara POS dengan kepuasan kerja (Nye \& Witt, 1993; pada Randall et al., 1999; Cropanzano et al., 1997).

Hipotesis:

$\mathrm{H} 2 \mathrm{a}$. Dukungan berhubungan secara positif dengan kepuasan kerja

\subsubsection{Dukungan organisasional dan turnover intent.}

Pekerja yang memandang dukungan yang rendah dari employer-nya akan lebih suka mencari pekerjaan di tempat lain (Guzzo et al., 1994; pada Wayne et al., 1997). Penelitian Wayne et al. (1997) menemukan bahwa dukungan organisasional yang dipersepsikan menjadi prediktor intensi untuk keluar.

Hipotesis: H2b. Dukungan berhubungan secara negatif dengan intensi untuk keluar

\subsubsection{Dukungan organisasional dan komitmen organisasional}

POS dijelaskan sebagai komitmen organisasi kepada pekerjanya. Pekerja yang mempersepsikan komitmen organisasi ini akan berkomitmen afektif pada organisasi mereka (Eisenberger et al., 1986). Beberapa studi menemukan bahwa secara signifikan terdapat korelasi antara POS dengan komitmen afektif (Shore \& Tetrick, 1991; Shore \& Wayne, 1993; Wayne et al.,1997; Randall et al., 1999), dan bahwa POS menjadi prediktor komitmen afektif (Wayne et al.,1997; Randall et al., 1999). Sedangkan untuk komitmen continuance, Studi Randall et al. (1999) dan Shore dan Tetrick (1991) menemukan bahwa POS secara signifikan tidak berkorelasi dengan komponen komitmen ini. Randall et al. (1999) juga menyatakan bahwa tidak ada studi sebelumnya yang secara bersama-sama memperhitungkan komitmen afektif dan continuance. Dalam studi ini, meskipun tidak dihipotesiskan, komitmen continuance akan tetap diikutsertakan dalam survey, untuk mengetahui apakah hasilnya akan mendukung (tidak ada hubungan signifikan antara komitmen continuance dengan politik dan dukungan organisasional) atau bertentangan dengan penelitian Randall et al. (1999). Wayne et al. (1997) menemukan bahwa pengalaman pekerja seperti berpartisipasi dalam pelatihan dan pengembangan formal maupun informal memiliki POS level tinggi. Hal ini sesuai dengan karakteristik komitmen normatif, yaitu pekerja yang mendapat benefit dari organisasi karena diberi pelatihan untuk meningkatkan ketrampilannya dan pengembangan diri akan memiliki kewajiban untuk tinggal dan memberikan timbal baliknya kepada organisasi. Sejalan dengan itu, saat organisasi melakukan investasi dan memberi pengakuan kepada pekerjanya, mereka mendorong peningkatan hubungan pertukaran sosial yang kuat (Wayne et al., 1997).

Hipotesis:

H2c. Dukungan berhubungan secara positif dengan komitmen afektif

$\mathrm{H} 2 \mathrm{~d}$. Dukungan berhubungan secara positif dengan komitmen normatif

\subsubsection{Dukungan organisasional dan Kinerja-OCB}

Randall et al. (1999), menyatakan bahwa organisasi yang mendukung adalah organisasi yang merasa bangga terhadap pekerja mereka, memberi kompensasi dengan fair, mengikuti kebutuhan pekerjanya. Setton et al. (1996) menyatakan bahwa dukungan organisasional yang dipersepsikan level tinggi akan menciptakan kewajiban bagi individu untuk memberikan timbal baliknya. Timbal balik ini berupa peningkatan usaha in-role dan extra-role yang mereka berikan (Lynch et al., 1999). Studi Shore dan Wayne (1993) menemukan bahwa POS menjadi prediktor OCB dan berhubungan positif dengan kinerja dan OCB. Pekerja yang merasa didukung oleh organisasi, akan memberikan timbal baliknya dan menurunkan ketidakseimbangan dalam hubungan tersebut dengan terlibat dalam perilaku citizenship (Shore \& Wayne, 1993).

Hipotesis:

H2e. Dukungan berhubungan secara positif dengan kinerja

H2f. Dukungan berhubungan secara positif dengan OCB

\subsection{Politik dan dukungan organisasional}


Studi Nge dan Witt (1993; pada Cropanzano et al., 1999) menemukan bahwa politik dan dukungan berkorelasi sangat tinggi, dan paling baik keduanya dipandang sebagai bangunan tunggal yang berada pada sisi berlawanan (Nge \& Witt, 1993; pada Randall et al., 1999). Namun menurut Cropanzano et al. (1997) hubungan tersebut masih tidak jelas, karena hasil confirmatory factor analytic menunjukkan bahwa keduanya dapat dimodelkan dengan satu atau dua model faktor. Studi Randall et al.(1999) menemukan hasil yang mendua, yaitu: pada saat dilakukan analisa dengan confirmatory factor analysis, politik dan dukungan organisasional ditemukan sebagai konstruk tunggal; dan pada saat analisa dengan multiple regression hasilnya adalah dua konstruk yang berbeda. Studi Copanzano et al. (1997) menemukan bahwa politik dan dukungan merupakan konstruk yang berbeda. Studi lain (Cropanzano et al., 1995; pada Randall et al., 1999) juga menunjukkan bukti bahwa keduanya adalah dua konstruk yang berbeda, karena keduanya memiliki fokus yang berbeda; persepsi politik ditujukan pada satu rekan kerja dan satu atasan. Sedangkan persepsi dukungan mengarah pada organisasi sebagai keseluruhan (George et al., 1993). Cropanzano et al. (1997) menyatakan bahwa jika politik atau dukungan dapat menjelaskan varians inkremental di atas dan melebihi yang lain, maka dapat dikatakan bahwa keduanya merupakan konstruk berbeda.

H3a. Politik organisasional menjelaskan varians inkremental secara signifikan dalam variabel dependen melebihi yang dapat dijelaskan oleh dukungan organisasional

$\mathrm{H} 3 \mathrm{~b}$. Dukungan organisasional menjelaskan varians inkremental secara signifikan dalam variabel dependen melebihi yang dapat dijelaskan oleh politik organisasional

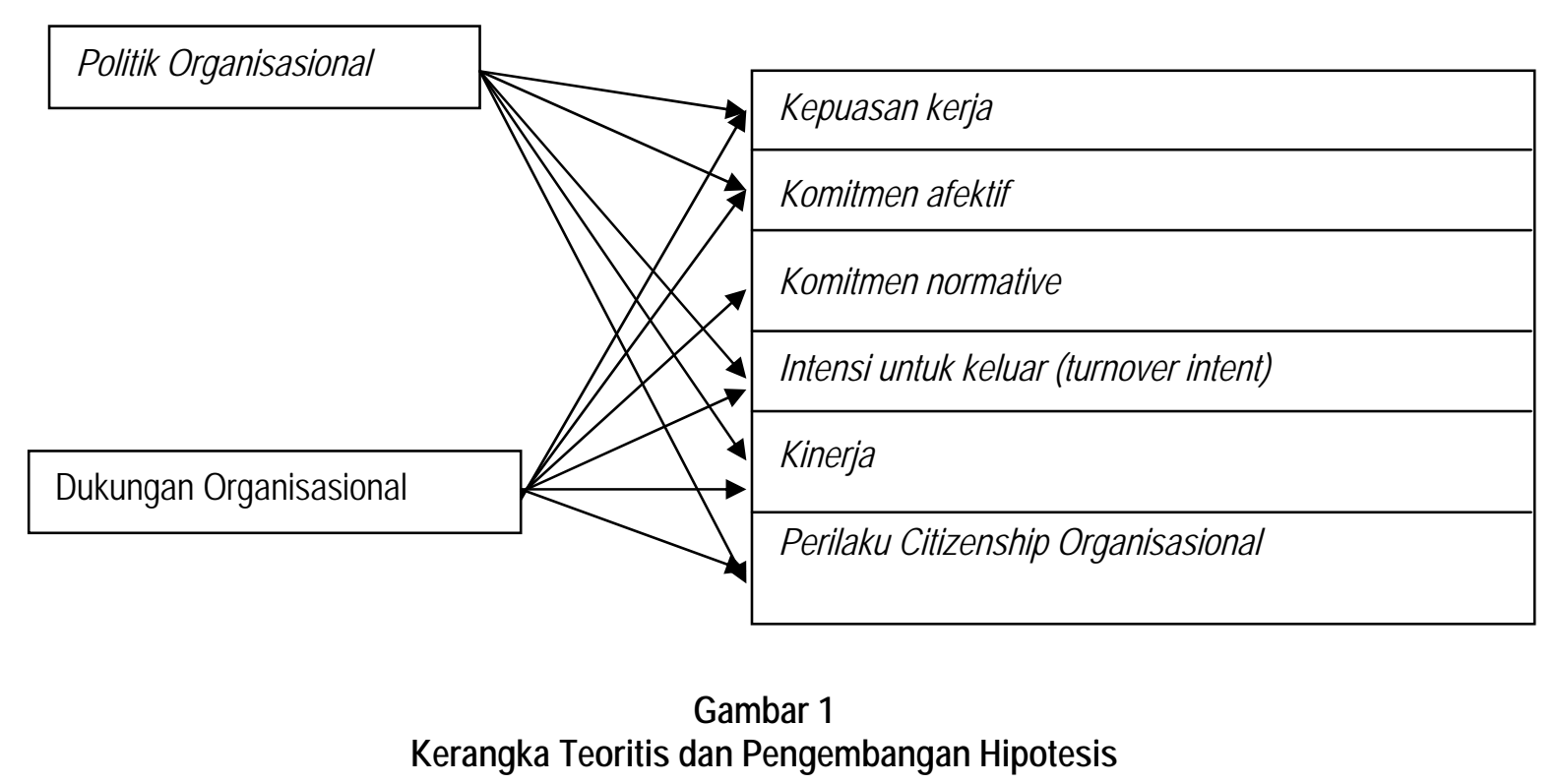




\section{MODEL RISET}

\subsection{Sampel dan prosedur pengumpulan data}

Sampel adalah 15 Kantor Akuntan Publik (KAP) di Surabaya. Pemilihan KAP dilakukan dengan cara random berdasarkan KAP yang terdaftar di buku direktori KAP tahun 1997-2000. Pengumpulan data dilakukan melalui kuesioner yang dikirim pada KAP yang dipilih dan bersedia diteliti. Jangka waktu pengisian adalah satu minggu setelah tanggal penyerahan, diambil kembali sepuluh hari setelah tanggal penyerahan. Berdasarkan observasi pada KAP dan akuntan publik, secara umum KAP memiliki karakteristik: tingkat perputaran Akuntan tinggi, rata-rata memiliki tingkat pendidikan yang sama (ada kesamaan pola pikir), berjiwa adaptif dan dinamis (mengikuti trend dan perubahan lingkungan), bekerja tidak dibatasi waktu dan ruang, dan mereka berusia produktif.

Ada 101 kuesioner untuk staf Kantor Akuntan Publik (senior dan yunior) dan 101 kuesioner penilaian kinerja dan OCB staf yang diberikan kepada supervisor. Satu supervisor dapat menilai lebih dari satu staf yang menjadi bawahannya. Jumlah kuesioner yang dikembalikan staf adalah 93 buah (response rate 92\%). Sedangkan 26 supervisor yang ikut berpartisipasi, mengembalikan 91 kuesioner penilaian kinerja dan OCB stafnya (response rate 90\%). Tabel 2 menunjukkan jumlah alokasi responden dari masing-masing KAP (nama KAP tidak dinampakkan sesuai kesepakatan dengan pihak KAP).

\subsection{Variabel Penelitian dan Pengukuran Variabel}

Politik organisasional diukur dengan 12 item Perceptions of Organizational Politic Scale (POPS) yang dikembangkan oleh Kacmar dan Ferris (1991). Dukungan organisasional diukur dengan 16 item Survey of Perceived Organizational Support (SPOS), yang dikembangkan Eisenberger et al. (1986), Shore dan Tetrick (1991), dan Shore dan Wayne (1993). Politik dan dukungan merupakan variabel independen

Kepuasan kerja diukur dengan 3 item Job Satisfaction Scale yang bukti validasinya didiskusikan oleh Seashore et al. (1982); dan Cropanzano et al. (1993). Komitmen organisasional, diukur dengan Affective Commitment Scale (ACS), Continuance Commitment Scale (CCS), dan Normative Commitment Scale (NCS), masing-masing terdiri dari 8 item. Berbagai ukuran ini dikembangkan oleh Allen dan Meyer (1990). Meskipun komitmen continuance tidak dihipotesiskan, variabel ini tetap diukur dengan tujuan mengetahui apakah hasil survei mendukung atau bertentangan dengan penelitian Randall et al. (1999) yang direplikasi dalam studi ini. Turnover intention diukur dengan 3 item dari Cropanzano et al. (1993). Pertanyaan untuk variabel-variabel ini ditujukan kepada staf senior dan yunior. Dua variabel dependen lain yaitu kinerja dan OCB, pertanyaannya ditujukan kepada supervisor dari staf senior dan yunior. Kinerja in-role diukur dengan 7 item dan OCB, item. Semua item dikembangkan Williams dan Anderson (1991). Semua ukuran menggunakan skala Likert 5 poin (sangat tidak setuju = 1 sampai sangat setuju $=5$ ).

Penelitian ini menggunakan variabel kontrol: jenis kelamin, usia, lamanya bekerja, dan status pernikahan. Ukuran usia dan lamanya bekerja diambil dari studi Allen dan Meyer (1993). Tabel 3 menunjukkan alokasi distribusi responden pada tiap variabel kontrol.

\subsection{Metoda analisis}

Prosedur analisis data yang digunakan adalah uji validitas dan reliabilitas (tabel 4), analisis korelasi untuk menguji hipotesis 1 dan 2, dan hierarchical regression analysis untuk menguji hipotesis 3 . Uji validitas dilakukan melalui pertimbangan expert dan pre test. Sedangkan uji reliabilitas dengan Cronbach alpha.

\section{ANALISIS DATA}

\subsection{Hasil analisis korelasi}

Hasil korelasi pada Tabel 5 menunjukkan bahwa politik organisasional secara signifikan berhubungan negatif dengan kepuasan kerja, komitmen afektif, dan kinerja; berhubungan positif dengan turnover intent; dan tidak berhubungan dengan OCB. Hasil ini mendukung hipotesis $1 \mathrm{a}, 1 \mathrm{~b}, 1 \mathrm{c}, 1 \mathrm{~d}$, tapi tidak mendukung hipotesis $1 \mathrm{e}$. Sedangkan, dukungan organisasional secara signifikan berhubungan positif dengan kepuasan kerja, komitmen afektif, continuance, dan normatif; berhubungan negatif dengan turnover intent; dan tidak berhubungan dengan kinerja dan OCB. Hasil ini mendukung hipotesis 2a, 2b, 2c, dan 2d 


\subsection{Analisis Regresi Hirarkikal}

Kepuasan kerja. Tabel 6 menunjukkan bahwa saat politik ditambahkan pada variabel kontrol, signifikan memberi tambahan penjelasan terhadap kepuasan kerja $\left(\Delta^{R^{2}=13.2 \% ;} p<0.01\right)$. Dukungan yang ditambahkan kemudian pada tahap 3, tidak secara signifikan menjelaskan varians inkremental dalam kepuasan kerja ( $\mathrm{R}^{2}$ adjusted tidak bertambah). Saat urutan dibalik, dukungan ditambahkan dahulu pada variabel kontrol, tidak secara signifikan dapat memberikan penjelasan varians inkremental. Namun saat politik dimasukkan dalam proses regresi, secara signifikan memberi penjelasan varians inkremental melebihi dukungan $\left(\Delta^{R}=6.5 \%\right.$, $p<0.05)$.

Turnover intent. Tabel 6 menunjukkan status pernikahan (0=belum menikah,1=sudah menikah) pada tiap tahap, secara signifikan berpengaruh negatif terhadap turnover intent. Hal ini menunjukkan bahwa staf yang belum menikah lebih mempunyai kecenderungan yang tinggi untuk keluar. Variabel kontrol secara signifikan $\left(\triangle^{\left.R^{2}=0.133, p<0.05\right)}\right.$ memberi penjelasan pada turnover intent. Setelah politik dimasukkan dalam proses regresi, $R^{2}$ mengalami peningkatan signifikan $\left(\triangle^{2}=17.1 \%, p<0.001\right)$. Pada tahap 3, saat dukungan ditambahkan dalam proses regresi, $R^{2}$ mengalami peningkatan yang signifikan $\left(\triangle R^{2}=3.7 \%, p<0.001\right)$ dan menjelaskan varians inkremental melebihi politik. Saat dukungan ditambahkan terlebih dulu pada variabel

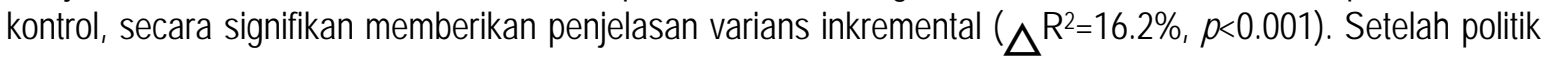
ditambahkan kemudian, signifikan dapat menjelaskan varians inkremental melebihi dukungan $\left(\Delta^{R^{2}=4.6 \%, p}\right.$ $<0.001)$

Komitmen afektif. Tabel 7 menunjukkan bahwa saat politik ditambahkan terlebih dulu pada variabel kontrol, secara signifikan menjelaskan varians inkremental pada tahap dua $\left(\Delta^{2}=19.4 \%, p<0.01\right)$. Namun setelah dukungan ditambahkan dalam proses regresi, secara signifikan menjelaskan varians inkremental melebihi politik pada komitmen afektif $\left(\Delta^{\left.R^{2}=8.5 \% ; p<0.001\right)}\right.$. Saat dukungan ditambahkan lebih dulu pada variabel kontrol, signifikan menjelaskan varians inkremental $\left(\triangle R^{2}=25 \%, p<0.001\right)$. Setelah politik ditambahkan dalam proses regresi, secara signifikan juga dapat menjelaskan varians inkremental melebihi dukungan dengan nilai yang sangat kecil $\left(\triangle^{2}=2.9 \%, p<0.001\right)$

Komitmen continuance. Tabel 7 menunjukkan bahwa politik (baik jika dimasukkan dalam proses regresi sebelum maupun sesudah dukungan) tidak secara signifikan menjelaskan varians inkremental dalam komitmen continuance. Dukungan juga tidak secara signifikan menjelaskan varians inkremental dalam komitmen ini, melebihi politik.

Komitmen normatif. Tabel 7 menunjukkan bahwa saat politik ditambahkan pada variabel kontrol, signifikan

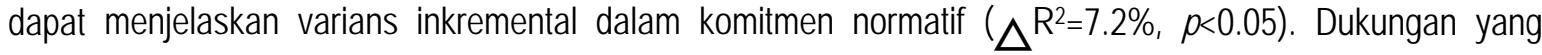
dimasukkan kemudian dapat secara signifikan menjelaskan varians inkremental namun nilainya sangat kecil. $\left(\triangle R^{2}=3 \%, p<0.05\right)$. Saat dukungan dimasukkan terlebih dahulu, secara signifikan menjelaskan varians inkremental $\left(\triangle \mathrm{R}^{2}=9.1 \%, p<0.05\right)$. Pada tahap tiga, setelah politik organisasional ditambahkan dalam regresi, signifikan menjelaskan varians inkremental dalam komitmen normatif melebihi dukungan $\left(\triangle R^{2}=1.1 \% ; p<0.05\right)$ Kinerja-OCB. Tabel 8 menunjukkan bahwa politik organisasional, baik ditambahkan sebelum atau sesudah dukungan, secara signifikan berpengaruh negatif pada kinerja namun tidak dapat menjelaskan varians inkremental dalam kinerja. Dukungan organisasional, baik ditambahkan sebelum atau sesudah politik, tidak secara signifikan menjelaskan varians inkremental dalam kinerja. Baik politik maupun dukungan organisasional tidak secara signifikan menjelaskan varians inkremental dalam OCB, melebihi satu sama lain.

\section{PEMBAHASAN DAN KESIMPULAN}

Dari hasil analisis korelasi, politik organisasional signifikan berhubungan negatif dengan kepuasan kerja, komitmen afektif, dan kinerja; berhubungan positif dengan turnover intent; tidak berhubungan dengan 
OCB. Dengan demikian, makin tinggi seseorang mempersepsikan politik organisasional, makin menurun kepuasan kerja, komitmen afektif, dan kinerjanya; dan makin meningkat turnover intent.

Perkecualian untuk kinerja, Randall et al. (1999) menemukan tidak ada hubungan antara politik dengan kinerja, meskipun sama dengan studi Randall et al. (1999), studi ini juga menggunakan supervisor untuk menilai kinerja. Namun studi Kacmar (1999) yang menggunakan penilaian kinerja oleh responden sendiri, menemukan hubungan signifikan antara keduanya. Penemuan bahwa politik tidak berhubungan dengan OCB bertentangan dengan studi Randall et al. (1999), namun memperkuat studi Cropanzano et al. (1997)

Dukungan secara signifikan berhubungan positif dengan kepuasan kerja, komitmen afektif, continuance, dan normatif, berhubungan negatif dengan turnover intent. Dengan demikian semakin tinggi persepsi seseorang akan dukungan organisasional, maka kepuasan kerja, komitmen afektif, continuance, dan normatifnya akan meningkat, dan akan menurunkan turnover intent. Penemuan bahwa dukungan berhubungan dengan kepuasan, turnover intent, dan komitmen afektif memperkuat studi Randall et al. (1999), Wayne et al. (1997).

Komitmen continuance, berkaitan dengan investasi pekerja dalam organisasi. Pekerja tetap tinggal di organisasi karena tidak mau kehilangan reward yang harus mereka terima sehubungan dengan investasi yang telah mereka keluarkan. Hasil uji menyatakan bahwa dukungan berhubungan positif dengan komitmen ini. Hal ini mungkin karena pekerja, mempersepsikan bahwa organisasi akan menilai kontribusi mereka dan memberikan reward sesuai dengan kontribusi itu (dalam dukungan ada unsur fair), dan memperhatikan kehidupan dan kesejahteraan mereka, komitmen continuance mereka akan meningkat. Hasil uji ini memperkuat penemuan Eisenberger et al. (1990; pada Shore \& Tetric, 1991); dan tidak mendukung penemuan Shore dan Tetric (1991) dan Randall et al. (1999). Namun demikian dukungan tidak dapat secara signifikan menjelaskan varians inkremental komitmen continuance.

Meski tidak dihipotesiskan, hasil analisis korelasi menunjukkan bahwa politik dan komitmen normatif berhubungan negatif. Penemuan ini menunjukkan bahwa komitmen normatif, yang secara teori muncul karena pengalaman sosialisasi, misalnya karena benefit yang sudah mereka terima. Jika pemberian benefit itu dipersepsikan pekerja ada permainan politik di dalamnya, maka komitmen normatif, atau kewajiban moral untuk tinggal di organisasi akan berkurang.

Penemuan bahwa dukungan tidak secara signifikan berhubungan positif dengan kinerja memperkuat hasil studi Settoon et al. (1996) dan Wayne et al. (1997). Penjelasan Wayne et al. (1997) adalah bahwa kinerja lebih berhubungan dengan Leader-Member Exchange (LMX), sehingga mungkin pekerja lebih memandang kinerja sebagai kewajiban pada atasan mereka bukan pada organisasi.

Hasil uji bahwa politik dan dukungan tidak secara signifikan berhubungan positif dengan OCB memperkuat penemuan Cropanzano et al. (1997), yang mendapat penjelasan bahwa supervisor tidak cukup pengetahuan menilai OCB pekerja. Apalagi dengan karakteristik sampel pada studi saat ini, staf kantor akuntan publik. Mungkin yang lebih diperhatikan adalah bagaimana mereka melakukan kerja 'in-role', yang sesuai dengan diskripsi kerja dan hasil kerjanya.

Status pernikahan (1='belum menikah', 2='sudah menikah'), di semua tahap regresi juga secara signifikan berhubungan (Tabel 5) dan berpengaruh negatif pada turnover intent (Tabel 6). Dengan kata lain, staf yang belum menikah punya kecenderungan lebih tinggi untuk berkeinginan keluar dari organisasi (turnover intent). Hal ini mungkin karena mereka yang belum menikah lebih leluasa untuk keluar masuk dari satu pekerjaan ke pekerjaan lain karena tidak ada keluarga yang ditanggung, dibanding mereka yang sudah menikah.

Untuk menguji hipotesis 3a dan 3b, digunakan alat analisis regresi hirarkikal. Tabel 9 menunjukkan rangkuman hasil analisis, berupa penambahan $\mathrm{R}^{2}$ yang diberikan oleh politik dan dukungan, saat politik ditambahkan pada variabel kontrol baru kemudian dukungan ditambahkan pada politik (politik I-dukungan II), maupun sebaliknya (dukungan I-politik II). Jika politik diregresi lebih dulu, dan kemudian dukungan, menunjukkan bahwa dukungan secara signifikan dapat menjelaskan varians inkremental dalam turnover intent, komitmen afektif, dan komitmen normatif; melebihi yang dijelaskan politik. Namun penambahan varians itu nilainya kecil, yaitu antara 3-8.5\%. Hasil ini memperkuat penemuan Randall et al. (1999), yaitu tambahan 
penjelasan dukungan pada turnover intent, dan komitmen afektif; dan penemuan Cropanzano et al. (1997), dalam menjelaskan komitmen afektif. Dengan demikian hipotesis $3 \mathrm{~b}$ didukung untuk 3 variabel dependen tersebut.

Jika uji regresi hirarkikal dilakukan dengan memasukkan dukungan kemudian politik, maka politik dapat menjelaskan varians inkremental dalam kepuasan kerja, turnover intent, komitmen afektif, komitmen normatif, melebihi dukungan. Namun tambahan varians itu juga kecil, antara 1,1\%-6.5\%. Dengan demikian hipotesis $3 b$ didukung untuk variabel kepuasan, turnover intent, komitmen afektif, dan komitmen normatif. Karena politik dan dukungan dapat menjelaskan varians inkremental melebihi satu sama lain, maka dapat dikatakan bahwa keduanya merupakan dua konstruk yang berbeda, meskipun keduanya berkorelasi (Wayne, 1993; pada Cropanzano et al., 1997)

Meskipun dukungan secara signifikan berhubungan positif dengan komitmen continuance, namun tidak signifikan untuk menjelaskan varians pada komponen komitmen ini. Berdasarkan observasi pada beberapa pimpinan KAP, mereka menyatakan bahwa turnover pekerja tinggi. Bekerja di KAP dapat dikatakan untuk mencari pengalaman. Karena akuntan publik berhubungan dengan pihak luar (client), maka kesempatan untuk bekerja di tempat lain cukup tinggi. Gaji yang diperoleh pun dapat lebih tinggi dibanding di KAP. Mungkin hal ini yang mendasari mengapa dukungan (dan politik) tidak signifikan menjelaskan komitmen continuance. Kesempatan yang terbuka dan gaji lebih besar menjadi prioritas mereka dibanding berkomitmen, tetap tinggal di organisasi untuk mendapat pengganti investasi mereka.

Dukungan tidak secara signifikan menjelaskan varians inkremental dalam kepuasan kerja (meski berhubungan dalam uji korelasi), dan politik organisasional yang secara signifikan menjelaskan varians inkremental dalam kepuasan kerja. Hasil ini bertentangan dengan penemuan Randall et al. (1999), yaitu bahwa hanya dukungan yang menjelaskan varians inkremental melebihi politik. Penemuan ini menunjukkan bahwa kepuasan kerja akuntan, berhubungan dengan dukungan organisasi, namun kepuasan itu akan lebih nampak jika politik organisasionalnya rendah.

Baik politik (meskipun secara signifikan berhubungan negatif dengan kinerja) maupun dukungan tidak dapat secara signifikan menjelaskan kinerja. Hasil ini memperkuat penemuan Randall et al. (1999). Ada banyak hal lain yang menjelaskan kinerja, dalam hal ini kinerja akuntan. Akuntan yang bekerja secara individual, berusaha memberikan kinerja yang baik, profesional demi mempertahankan status profesi dan citra masyarakat pengguna jasanya yang akan menjamin karir jangka panjang mereka. Selain itu, kinerja baik mungkin karena ingin menjalin hubungan baik dengan client. Hubungan baik ini diharapkan membuka kesempatan bekerja di tempat client mereka karena posisi dan gaji yang lebih baik.

Sedangkan OCB, seperti yang telah dijelaskan di atas, supervisor tidak cukup pengetahuan untuk menilai OCB staf. Apalagi bagi mereka yang bekerja di KAP, dengan mobilitas kerja tinggi, deadline pengumpulan laporan yang harus dipenuhi, maka hal ini mungkin menyulitkan atau tidak memungkinkan bagi supervisor untuk mengetahui hal-hal selain kinerja in-role bawahannya.

Rendahnya varians inkremental yang dijelaskan oleh variabel independen, sama dengan penemuan pada studi terdahulu (misal: Randall et al., 1999; Cropanzano et al., 1997). Hal ini mungkin karena adanya hubungan atau interkorelasi antara variabel-variabel independen, yang biasa terjadi dalam analisis regresi berganda. Hair et al.(1998) menyatakan bahwa kemampuan variabel independen yang ditambahkan pada proses regresi untuk meningkatkan prediksi terhadap variabel dependen tidak hanya berkaitan dengan korelasinya dengan variabel dependen tersebut, tapi juga korelasi variabel independen yang ditambahkan dengan variabel independen yang sudah ada pada proses regresi itu. Dampaknya adalah menurunnya varians yang dapat dijelaskan oleh variabel independen dan penentuan kontribusi masing-masing variabel independen makin sulit.

\section{IMPLIKASI DAN KETERBATASAN}

Kepuasan kerja, komitmen, dan turnover intent ditemukan berhubungan dengan, dan dapat dijelaskan oleh politik dan dukungan organisasional. Oleh karenanya, ketiganya penting untuk dikelola karena keberhasilan 'penjualan' jasa KAP dan mempertahankan client, sangat tergantung pada penyedia jasa, yaitu para akuntan. Mereka ini menjadi inti posisi perusahaan dan menjadi jasa itu sendiri, langsung mempengaruhi mutu produk, 
harga, dan image perusahaan (Ellis \& Mosher, 1993). Jika KAP dapat mempertahankan pekerjanya, apalagi jika pekerja tersebut berkualitas, maka kelangsungan hubungan jangka panjang KAP dan clientnya akan lebih terjamin, karena bagaimanapun yang berhadapan langsung dengan client adalah para akuntan tersebut. Agar pekerja dapat dipertahankan, maka mutu jasa internal harus ditingkatkan lebih dulu, antara lain melalui dukungan organisasional.

Namun demikian, dalam studi ini juga ditemukan bahwa politik dan dukungan merupakan konstruk yang berbeda, sehingga jika dukungan itu ada, maka tidak menutup kemungkinan munculnya politik. Karena itu, KAP perlu mengelola keberadaan politik dan dukungan, dengan makin meningkatkan dukungan (misalnya: disain kerja yang menarik, penghargaan, pelatihan, peningkatan kesejahteraan, fair dalam promosi dan penggajian, lingkungan kerja yang nyaman) dan menurunkan perilaku politik. Perilaku politik biasanya muncul saat ada ketidakjelasan, misalnya dalam kriteria penilaian, struktur karir, persyaratan. Dengan demikian, organisasi perlu menetapkan kriteria yang berhubungan dengan 'masa depan' pekerja (seperti karir, promosi) dengan jelas, sehingga pengukuran dan keputusan yang diambil juga berdasarkan rasionalis dan bukan politis.

Penilaian OCB dinilai oleh supervisor dan hasil analisis data menunjukkan bahwa baik politik maupun dukungan tidak mempunyai hubungan signifikan dengan OCB. Pada penelitian berikutnya pengujian dapat dilakukan dengan memberikan penilaian kepada pekerja/responden sendiri (self-reported) dan/atau kepada rekan kerja.

Jika pada penelitian ini sampelnya adalah akuntan sebagai "kaum" profesional yang terikat dengan kode etik tertentu, mungkin pada pada penelitian berikutnya dapat diambil sampel dari kaum profesional lain, misalnya dokter yang bekerja di rumah sakit, perawat, guru/dosen; untuk memperkuat hasil penelitian ini, khususnya tentang hubungan politik dan kinerja. Hal ini berkaitan dengan pembahasan hasil, yaitu meskipun politik berhubungan negatif dengan kinerja, tidak dapat secara signifikan menjelaskan kinerja. Mungkin hal ini karena adanya kode etik profesi, yang menuntut mereka untuk tetap berkinerja baik.

Berkaitan dengan sampel penelitian ini yaitu akuntan publik, yang dalam kenyataannya bekerja dalam mobilitas tinggi (misal: deadline kerja, kunjungan ke client), maka jumlah item pertanyaan menjadi pertimbangan penting. Hal ini membatasi penulis dalam memilih alat ukur dan jumlah item pertanyaan. Dalam penelitian selanjutnya mungkin dapat digunakan alat ukur lain, terutama dalam pengukuran kepuasan kerja. Penelitian saat ini hanya menggunakan versi pendek instrumen pengukuran kepuasan kerja (3 item). Dalam literatur tersedia instrumen lain yang mungkin dapat mengukur secara lebih lengkap/seksama, dengan tetap memperhatikan jumlah item dan responden sasarannya.

\section{DAFTAR PUSTAKA}

Allen, N. J., \& Meyer, J. P. (1990), "The measurement and antecedent of affective, continuance and normative commitment to the organization", Journal of Occupational Psychology, 63 pp.1-18.

Allen, N. J., \& Meyer, J. P. (1993), "Organizational commitment: Evidence of career stage effects?" Journal Business Research, 26 pp. 49-61.

Becker, B., \& Gerhart, B. (1996), "The impact of human resource management on organizational performace: Progress and prospects", Academy of Management Journal, 39 (4) pp. 779-801.

Brooke, P. P., Jr., Russell, D. W., \& Price, J. L. (1988), "Discriminant validation of measures of job satisfaction, job involvement, and organizational commitment", Journal of Applied Psychology, 73 (2) pp.139-145.

Butler, T., \& Waldroop, J. (1999), "Job sculpting. The art of retaining your best people", Harvard Business Review, September-October pp. 144-152. 
Cavanaugh, M. A., \& Noe, R. A., (1999), "Antecedents and consequences of relational components of the new psychological contract", Journal of Organizational Behavior, 20 pp. 323-340.

Chay, Yue-Wah, \& Aryee, S., (1999), "Potential moderating influence of career growth opportunities on careerist orientation and work attitudes: evidence of the protean career era in Singapore", Journal of Organizational Behavior, 20 pp. 613-623.

Cohen, A, \& Vigoda, E., (1999), "Politics and the workplace. An empirical examination of the relationship between political behavior and work outcomes", Public Productivity \& Management Review. 20 (3) pp. 389-406.

Crane, F. G., (1993), "Professional service marketing in the future: Challenges and solutions", Journal of Professional Service Marketing, 9 (1) pp.3-12.

Cropanzano, R., Howes, J. C., Grandey, A. A., \& Toth, P., (1997), "The relationship of organizational politics and support to work behaviors, attitudes, and stress", Journal of Organizational Behavior, 18 pp.159180.

Deckop, J. R., Mangel, R., \&Cirka, C. C., (1999), "Getting more than you pay for: organizational citizenship behavior and pay-for-performance plans", Academy of Management Journal, 42 (4) pp. 420-428.

Drory, A., (1993), Perceived political climate and job attitudes. Organization Studies. 14 pp. 59-71.

Eisenberger, R., Huntington, R., Hutchison, S., \& Sowa, D., (1986), "Perceived organizational support", Journal of Applied Psychology, 71 (3) pp. 500-507.

Ellis, B. \& Mosher, J. S., "1993), "Six Ps for four characteristics: A complete positioning strategy for the professional services firm-CPA's", Journal of Professional Service Marketing, 9 (1) pp. 129-145.

Ferris, G. R. \& Kacmar, K. M., (1992), "Perceptions of organizational politics", Journal of Management, 18 (1) pp. 93-116.

, \& King, T. R., (1991), "Politics in human resources decision: a walk on the dark side", Organizational Dynamics, 20 (2) pp. 59-72.

George, J. M., Reed, T. F., Ballard, K. A., Colin, J., \& Fielding, J., (1993), "Contact with AIDS patients as a sources of work-related distress: Effects of organizational and social support", Academy Management .Journal, 36 (1) pp. 157-171.

Gibson, J. L., Ivancevich, J. M., \& Donnelly, J. H., Jr., (1997), Organizations. Behavior, structure, Processes. Boston, USA: Irwin-Burr Ridge.

Gomez-Mejia, L. R., Balkin, D. B., \& Cardy, R. L., (1995), Managing Human Resources. New Jersey, USA: Prentice-Hall.

Greenberg, J., \& Baron, R. A.,(1997), Behavior in organizations: Understanding and managing the human side of work. New Jersey, USA: Prentice-Hall International, INC. 
Hagedoorn, M., Van Yperen, N. W., Van De Vliert, E., \& Buunk, B. P., (1999), "Employees' reactions to problematic events: A circumplex structure of five catagories of responses, and the role of job satisfaction", Journal of Organization Behavior, 20 pp. 309-321.

Hair, J.F, Jr, Anderson, R. E, Tatham, R. L., \& Black, W.C., (1998), Multivariate data analysis. New Jersey, USA: Prentice-Hall.

Harrell-Cook, G., Ferris, G. R., \& Dulebohn, J. H., (1999), "Political behaviors as moderators of the perceptions of organizational politics-work outcomes relationships", Journal of Organization Behavior, 20 pp. 1093-1105.

Hermason, R. H., Carcello, J. V., Hermason, D. R., Milano, B. J., Polansky, G. A., Williams, D. Z., (1995), "Better environment, better staff", Journal of Accountancy, April pp. 39-43.

Heskett, J. L., Jones, T. O., Loveman, G. W., Sasser, W. E.,Jr., \& Schlesinger, L. A., (1994), "Putting the service-profit chain to work", Harvard Business Review, Maret-April pp. 164-174.

Johnston, M. W., Griffeth, R. W., Burton, S., \& Carson, P. P., (1993), "An exploratory investigation into the relationships between promotion and turnover: A quasi-experimental longitudinal study", Journal of Management, 19 (1) pp. 33-49.

Kacmar, K.M., Bozeman, D. P., Carlson, D. S., \& Anthony, W. P., (1999), "An examination of the perception of organizational politics model: Replication and extention", Human Relation, 52 (3) pp. 383-416.

Konovsky, M.A. \& Pugh, S. D., (1994), "Citizenship behavior and social exchange", Academy Management Journal, 37 (3) pp. 656-669.

Landsbergis, P. A., \& Vivona-Vaughan, E., (1995), "Evaluation of an occupational stress intervention in a public agency", Journal of organizational Behavior, 16 pp. 29-48.

Longenecker, C. O., Sims, H.P., Jr., \& Gioia, D. A., (1987), "Behind the mask: The politics of employee appraisal", The Academy of Management Executive, 1 (3) pp. 183-193.

Lovelock, C. H., (1996), Service marketing. New Jersey, USA: Prentice Hall International Edition. Edisi ketiga

Luthans F., (1995), Organizational Behavior. Singapore, Singapore: McGraw-Hill International Edition.

Lynch, P. D., Eisenberger, R., \& Armeli, S., (1999), "Perceived organizational support: Inferior versus superior performance by wary employees", Journal of Applied Psychology, 84 (4) pp. 467-483.

Maslyn, J. M., \& Fedor, D. B., (1998), "Perceptions of politics: Does measuring different foci matter?" Journal of Applied Psychology, 84 (4) pp. 645-653.

Meyer, J. P., Allen, N. J., \& Smith, C. A., (1993), "Commitment to organizations and occupations: Extention and test of a three-component conceptualization", Journal of applied psychology, 78 (4) pp. 538551.

Meyer, J. P. \& Allen, N. J., (1993), "Organizational commitment: evidence of career stage effects?" Journal of Business Research, 26 pp. 49-61. 
Mobley, W. H., Griffeth, R. W., Hand, H. H., \& Meglino, B. M., (1979), "Review and conceptual analysis of the employee turnover process", Psychological Bulletin, 86 (3): 493-522.

Nadirsyah., (1993), "Persepsi pemakai informasi akuntansi, akuntan dan masyarakat umum terhadap independensi akuntan publik", Tesis pada program pascasarjana program studi akuntansi jurusan ilmu-ilmu sosial Universitas Gadjah Mada Yogyakarta.

Nelson, D. L. \& Quick, J. C., (1997), Organizational behavior. Foundation, realities, and challanges. Minneapolis, USA: West Publishing Company.

Randall, M.L., Cropanzano, R., Bormann, C.A., \& Birjulin, A., (1999), "Organizational politics and organizational support as a predictor of work attitudes, job performance, and organizational Citizenship Behavior", Journal of Organizational Behavior, 20 pp. 159-174.

Robinson, S.L., Kraatz, M.S., \& Rousseau, D.M., (1994), "Changing obligations and the psychological contract: A longitudinal study", Academy Management Journal, 37 (1) pp. 137-152.

Roome, N., (1994), "Business strategy, R\&D, management and enviromental imperatives", R\&D Management, 24 (1) pp. 65-82.

Samekto, A., (2000), "Perbedaan kinerja laki-laki dan wanita pada kantor akuntan publik di Surabaya", Tesis pada program pascasarjana program studi akuntansi jurusan ilmu-ilmu sosial Universitas Gadjah Mada Yogyakarta.

Sekaran, U., (1992), Research Methods for Business: A Skill-Building Approach. Singapore, Singapore: John Wiley \& Sons, Inc.

Setton, R. P., Bennet, N., \& Liden, R. C., (1996), "Social exchange in organizations: Perceived organizational support, leader-member exchange, and employee reciprocity", Journal of Applied Psychology, 81 (3) pp. 219-227.

Shore, L. M. \& Tetrick, L. E., (1991), "A construct validity study of the survey of perceived organizational support", Journal of Applied Psychology, 76 (5) pp. 637-643.

, \& Wayne, S. J., (1993), "Commitment and employee behavior: Comparison of affective commitment and continuance commitment with perceived organizational support", Journal of Applied Psychology, 78 (5) pp. 774-780.

Soewardjono., (2000), Peran pendidikan tinggi di bidang ekonomi dalam meningkatkan profesionalisme. Makalah disampaikan dalam seminar setengah hari Dies Natalis ke-20 Program Magister Sains dan Doktor Ilmu-ilmu : Ekonomi dan Studi Pembangunan, Manajemen, dan Akuntansi Universitas Gadjah Mada Yogyakarta.

Somers, M. J., \& Birnbaum, D., (1998), "Work-related commitment and job performance: It's also the nature of the performance that counts", Journal of Organizational Behavior, 19: pp. 621-634.

Stone, R. J., (1991), Human Resources Management. Singapore, Singapore: John Wiley \& Sons.

Stroh, K. L. \& Reilly, A. H., (1997), Loyalty in the age of downsizing. Sloan Management Review, Summer pp. 83-88. 
Van Dyne, L., Graham, J.W., \& Dienesch, R. M., (1994), "Organizational citizhenship behavior: Construct redefinition, measurement, and validation", Academy Management Journal, 37 (4) pp. 765-802.

Van Dyne, L., \& Ang, Soon., (1998), "Organizational citizenship behavior of contingent workers in Singapore", Academy Management Journal, 41 (6) pp. 692-703.

Wayne. S. J., Shore, L. M., \& Liden, R. C., (1997), "Perceived organizational support and leader-member exchange: A social exchange perspective", Academy Management Journal, 40 (1) pp. 80-111. 


\section{Lampiran}

Tabel 1.

Hasil beberapa penelitian yang masih bertentangan

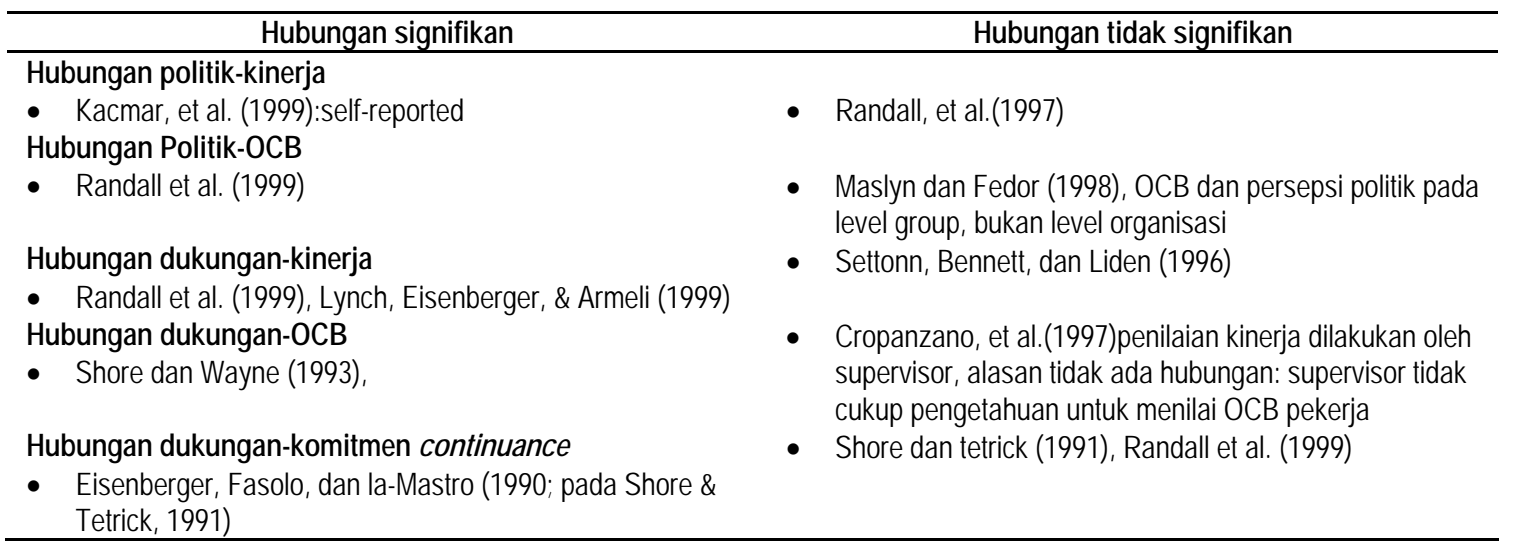

Tabel 2

Alokasi jumlah kuesioner yang dikembalikan staf dan supervisor masing-masing KAP

\begin{tabular}{|c|c|c|c|c|c|}
\hline \multirow[b]{2}{*}{ No. } & \multirow[b]{2}{*}{ Nama KAP } & \multicolumn{2}{|c|}{ Staf } & \multicolumn{2}{|c|}{ Supervisor } \\
\hline & & $\begin{array}{l}\text { Kuesioner yang } \\
\text { dibagikan }\end{array}$ & Kuesioner kembali & $\begin{array}{c}\text { Kuesioner yang } \\
\text { dibagikan }\end{array}$ & Kuesioner kembali \\
\hline 1. & KAP 1 & 2 & 2 & 2 & 2 \\
\hline 2. & KAP 2 & 9 & 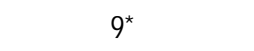 & 9 & 8 \\
\hline 3. & KAP 3 & 6 & $6^{\star *}$ & 6 & 4 \\
\hline 4. & KAP 4 & 10 & 10 & 10 & 10 \\
\hline 5. & KAP 5 & 10 & 9 & 10 & $10^{* \star *}$ \\
\hline 6. & KAP 6 & 10 & 10 & 10 & 10 \\
\hline 7. & KAP 7 & 4 & 4 & 4 & 4 \\
\hline 8. & KAP 8 & 0 & 5 & 5 & 5 \\
\hline 9. & KAP 9 & 10 & 8 & 10 & 8 \\
\hline 10. & KAP 10 & 5 & 5 & 5 & 5 \\
\hline 11. & KAP 11 & 5 & 5 & 5 & 5 \\
\hline 12. & KAP 12 & 10 & 7 & 10 & 7 \\
\hline 13. & KAP 13 & 5 & 3 & 5 & 3 \\
\hline 14. & KAP 14 & 5 & 5 & 5 & 5 \\
\hline 15. & KAP 15 & 5 & 5 & 5 & $5^{\star \star \star \star}$ \\
\hline & Jumlah & 101 & 93 & 101 & 91 \\
\hline
\end{tabular}

\section{Keterangan:}

* $\quad$ Dari 9 kuesioner staf yang kembali, ada 1 staf yang tidak disertai penilaian supervisornya.

** Dari 6 kuesioner staf yang kembali, ada 2 staf yang tidak disertai penilaian supervisornya.

*** Dari 10 kuesioner penilaian supervisor yang kembali ada 1 yang tidak disertai staf yang dinilai

**** Dari 5 kuesioner penilaian supervisor yang kembali, ada 1 kuesioner yang tidak disertai kuesioner staf (staf mengisi tidak lengkap) 
Tabel 3

Distribusi Frekuensi dan persentase data penelitian responden staf

\begin{tabular}{llcc}
\hline \multicolumn{1}{c}{ Nama Variabel } & \multicolumn{1}{c}{ Alternatif pilihan } & Frekuensi & Prosentase \\
\hline Jenis kelamin & Pria & 49 & $55.1 \%$ \\
& Wanita & 40 & $44.9 \%$ \\
Total & & 89 & $100 \%$ \\
Usia & $<31$ th & 64 & $71.9 \%$ \\
& $31-44$ th & 24 & $27 \%$ \\
& $>44$ th & 1 & $1.1 \%$ \\
Total & & 89 & $100 \%$ \\
Lama kerja & $<2$ th & 29 & $32.6 \%$ \\
& $2-10$ th & 58 & $65.2 \%$ \\
Total & $>10$ th & 2 & $2.2 \%$ \\
Status pernikahan & & 89 & $100 \%$ \\
& belum menikah & 60 & $67.4 \%$ \\
Total & sudah menikah & 29 & $32.6 \%$ \\
\hline
\end{tabular}

Tabel 4

Uji Reliabilitas

\begin{tabular}{llccccc}
\hline No. & \multicolumn{1}{c}{ Nama variabel } & $\begin{array}{c}\text { Jumlah } \\
\text { Item }\end{array}$ & $\begin{array}{c}\text { Cronbach } \\
\text { Alpha }\end{array}$ & $\begin{array}{c}\text { Jumlah item } \\
\text { dibuang }\end{array}$ & $\begin{array}{c}\text { Jumlah item } \\
\text { sisa }\end{array}$ & $\begin{array}{c}\text { Cronbach } \\
\text { Alpha }\end{array}$ \\
\hline 1 & Politik organisasional & 12 & 0.7298 & 2 & 10 & 0.7987 \\
2 & Dukungan organsiasional & 16 & 0.8726 & 2 & 14 & 0.8927 \\
3 & Kepuasan kerja & 3 & 0.5518 & 1 & 2 & 0.6072 \\
4 & Turnover intent & 3 & 0.7672 & - & 3 & 0.7672 \\
5 & Komitmen afektif & 8 & 0.7548 & 1 & 7 & 0.7675 \\
6 & Komitmen continuance & 8 & 0.7504 & - & 8 & 0.7504 \\
7 & Komitmen normatif & 8 & 0.5022 & 3 & 5 & 0.6313 \\
8 & Kinerja & 7 & 0.7721 & 2 & 5 & 0.8467 \\
9 & OCB & 14 & 0.7478 & 3 & 11 & 0.7798 \\
\hline
\end{tabular}


Tabel 5

Uji Korelasi

\begin{tabular}{|c|c|c|c|c|c|c|}
\hline & Jenis kelamin & Usia & Lama kerja & $\begin{array}{c}\text { Status } \\
\text { pernikahan }\end{array}$ & $\begin{array}{c}\text { Politik } \\
\text { organisa } \\
\text { sional }\end{array}$ & $\begin{array}{c}\text { Dukungan } \\
\text { organisa } \\
\text { sional }\end{array}$ \\
\hline \multicolumn{7}{|l|}{ Jenis kelamin } \\
\hline Usia & $-0.315^{\star \star}$ & & & & & \\
\hline Lama kerja & 0.095 & $0.412^{\star \star}$ & & & & \\
\hline Status pernikahan & $-0.243^{\star}$ & $0.577^{\star \star}$ & $0.369 * \star$ & & & \\
\hline Politik organisasional & -0.046 & -0.133 & -0.112 & -0.012 & & \\
\hline $\begin{array}{l}\text { Dukungan } \\
\text { organisasional }\end{array}$ & -0.062 & 0.161 & 0.088 & 0.081 & $-0.611^{\star *}$ & \\
\hline Kepuasan kerja & 0.141 & 0.010 & 0.147 & 0.078 & -0.371 ** & $0.263^{\star \star}$ \\
\hline Turnover intent & 0.129 & -0.140 & -0.072 & -0.350 ** & $0.392^{\star \star}$ & $-0.415^{\star \star}$ \\
\hline Komitmen afektif & -0.061 & 0.105 & 0.009 & 0.150 & $-0.432 * *$ & $0.506^{\star \star}$ \\
\hline Komitmen continuance & -0.034 & -0.035 & -0.132 & 0.107 & -0.095 & $0.195^{\star}$ \\
\hline Komitmen normatif & $-0.176^{\star}$ & 0.111 & -0.107 & -0.025 & $-0.266^{\star \star}$ & $0.314^{\star *}$ \\
\hline Kinerja & 0.037 & 0.049 & -0.051 & 0.024 & $-0.192^{*}$ & 0.034 \\
\hline OCB & 0.164 & 0.089 & 0.147 & 0.137 & -0.109 & -0.041 \\
\hline
\end{tabular}

Keterangan: *Korelasi signifikan pada $0.05,{ }^{* *}$ korelasi signifikan pada 0.01

Tabel 6

Analisis Regresi Hirarkikal (standardized coefficients), N = 89

Kepuasan Kerja dan Turnover Intent

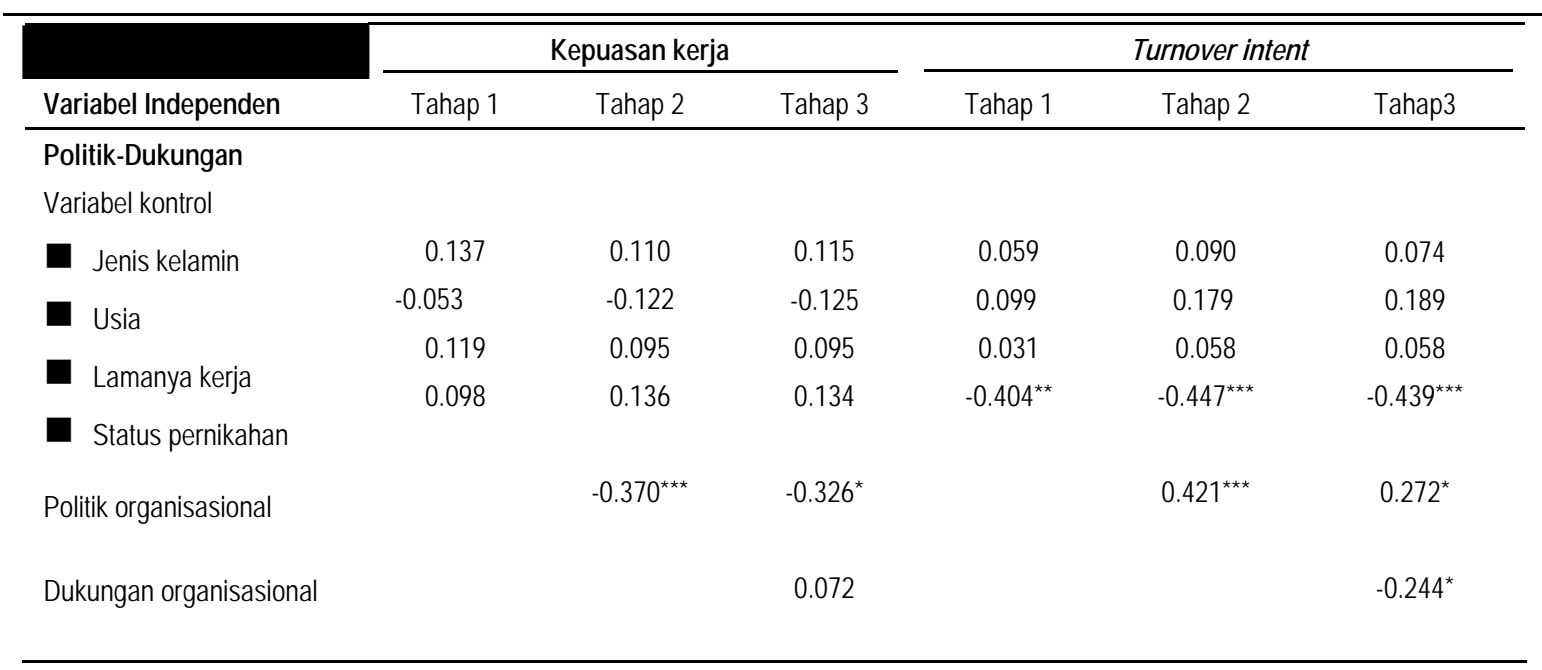




\begin{tabular}{|c|c|c|c|c|c|c|}
\hline & \multicolumn{3}{|c|}{ Kepuasan kerja } & \multicolumn{3}{|c|}{ Turnover intent } \\
\hline Variabel Independen & Tahap 1 & Tahap 2 & Tahap 3 & Tahap 1 & Tahap 2 & Tahap3 \\
\hline $\mathrm{R}^{2}$ & 0.044 & 0.176 & 0.180 & 0.133 & 0.304 & 0.341 \\
\hline Adjusted $\mathrm{R}^{2}$ & -0.001 & 0.127 & 0.120 & 0.092 & 0.262 & 0.292 \\
\hline $\mathrm{F}$ & 0.967 & $3.554^{\star \star}$ & $2.991^{*}$ & $3.217^{*}$ & $7.247^{\star \star \star}$ & $7.057^{\star \star \star}$ \\
\hline$\Delta \mathrm{R}^{2}$ & & 0.132 & 0.00 & & 0.171 & 0.037 \\
\hline \multicolumn{7}{|l|}{ Dukungan-Politik } \\
\hline \multicolumn{7}{|l|}{ Variabel kontrol } \\
\hline Jenis kelamin & 0.137 & 0.143 & 0.115 & 0.059 & 0.050 & 0.074 \\
\hline U Usia & -0.053 & -0.095 & -0.125 & 0.099 & 0.163 & 0.189 \\
\hline & 0.119 & 0.109 & 0.095 & 0.031 & 0.046 & 0.058 \\
\hline - Lamanya kerja & 0.098 & 0.106 & 0.134 & -0.40 & $-0.416^{\star \star}$ & $-0.439 * * \star$ \\
\hline Status pernikahan & & & & & & \\
\hline Dukungan organisasional & & $0.269 *$ & 0.072 & & $-0.409 * \star \star$ & $-0.244^{*}$ \\
\hline Politik organisasional & & & -0.32 & & & $0.272^{*}$ \\
\hline $\mathrm{R}^{2}$ & 0.044 & 0.115 & 0.180 & 0.133 & 0.295 & 0.341 \\
\hline Adjusted $\mathrm{R}^{2}$ & -0.001 & 0.061 & 0.120 & 0.092 & 0.253 & 0.292 \\
\hline $\mathrm{F}$ & 0.967 & 2148 & $2.991^{*}$ & $3.217^{* *}$ & $6.953^{\star \star \star}$ & $7.057^{\star \star *}$ \\
\hline$\Delta \mathrm{R}^{2}$ & & & 0.065 & & 0.162 & 0.046 \\
\hline$<0.05,{ }^{* *} p<0.01,{ }^{* * \star} p<$ & & & & & & \\
\hline
\end{tabular}


Tabel 7

Analisis Regresi Hirarkikal (standardized coefficients), N = 89

Komitmen Afektif, Continuance, dan Normatif

\begin{tabular}{|c|c|c|c|c|c|c|c|c|c|}
\hline & \multicolumn{3}{|c|}{ Komitmen Afektif } & \multicolumn{3}{|c|}{ Komitmen Continuance } & \multicolumn{3}{|c|}{ Komitmen Normatif } \\
\hline $\begin{array}{c}\text { Variabel } \\
\text { Independen }\end{array}$ & Tahap 1 & Tahap 2 & Tahap 3 & Tahap 1 & Tahap 2 & Tahap 3 & Tahap 1 & Tahap 2 & Tahap 3 \\
\hline \multicolumn{10}{|c|}{ Politik-Dukungan } \\
\hline \multicolumn{10}{|l|}{ Variabel kontrol } \\
\hline \multicolumn{10}{|c|}{ Jenis kelamin } \\
\hline Usia & -0.005 & -0.038 & -0.012 & 0.011 & 0.001 & 0.016 & -0.13 & -0.152 & -0.137 \\
\hline J Jmanva & 0.045 & -0.039 & -0.054 & -0.088 & -0.113 & -0.121 & 0.192 & 0.141 & 0.132 \\
\hline kerja & -0.063 & -0.092 & -0.091 & -0.181 & -0.190 & -0.189 & & -0.147 & -0.146 \\
\hline $\begin{array}{l}\text { Status } \\
\text { pernikahan }\end{array}$ & 0.146 & 0.192 & 0.179 & 0.228 & 0.241 & 0.234 & -0.120 & -0.092 & -0.100 \\
\hline \multicolumn{10}{|l|}{$\begin{array}{l}\text { Politik organisa } \\
\text { sional }\end{array}$} \\
\hline \multicolumn{10}{|l|}{$\begin{array}{l}\text { Dukungan } \\
\text { organisa }\end{array}$} \\
\hline & & & $0.373^{\star *}$ & & & 0.214 & & & 0.222 \\
\hline $\mathrm{R}^{2}$ & 0.026 & 0.220 & 0.305 & 0.051 & 0.067 & 0.095 & 0.061 & 0.133 & 0.163 \\
\hline Adjusted R2 & -0.020 & 0.173 & 255 & 0.006 & 0.011 & 0.029 & 0.017 & 0.081 & 0.102 \\
\hline $\mathrm{F} \widehat{ }$ & 0.571 & $4.673^{* *}$ & $6.010^{* * *} 0$. & 1.132 & 1.194 & 1.441 & 1.370 & $2.541^{*}$ & $2.663^{*}$ \\
\hline $\overrightarrow{\mathrm{R}^{2}}$ & & & & & 0.016 & 0.028 & & 0.072 & 0.03 \\
\hline
\end{tabular}


Tabel 8

Analisis Regresi Hirarkikal (standardized coefficients), $N=89$, Kinerja dan OCB

\begin{tabular}{|c|c|c|c|c|c|c|}
\hline & & Kinerja & & & OCB & \\
\hline Variabel independen & Tahap 1 & Tahap 2 & Tahap 3 & Tahap 1 & Tahap 2 & Tahap3 \\
\hline \multicolumn{7}{|l|}{ Politik-Dukungan } \\
\hline \multicolumn{7}{|l|}{ Variabel kontrol } \\
\hline Jenis kelamin & 0.089 & 0.074 & 0.065 & 0.208 & 0.202 & 0.190 \\
\hline [ Usia & 0.110 & 0.074 & 0.080 & 0.053 & 0.037 & 0.044 \\
\hline - Lamanya kerja & -0.114 & -0.127 & -0.127 & 0.055 & 0.049 & 0.049 \\
\hline - Status pernikahan & 0.024 & 0.044 & 0.049 & 0.137 & 0.146 & 0.151 \\
\hline Politik organisasional & & -0.192 & $-0.275^{\star}$ & & -0.088 & -0.191 \\
\hline Dukungan organisasional & & & -0.136 & & & -0.170 \\
\hline $\mathrm{R}^{2}$ & 0.015 & 0.051 & 0.062 & 0.066 & 0.073 & 0.091 \\
\hline Adjusted $\mathrm{R}^{2}$ & -0.032 & -0.006 & -0.006 & 0.021 & 0.017 & 0.024 \\
\hline $\mathrm{F}$ & 0.324 & 0.889 & .906 & 1.475 & 1.309 & 1.366 \\
\hline$\Delta \quad \mathrm{R}^{2}$ & & & & & 0.007 & 0.018 \\
\hline \multicolumn{7}{|l|}{ Dukungan-Politik } \\
\hline \multicolumn{7}{|l|}{ Variabel kontrol } \\
\hline Jenis kelamin & 0.089 & 0.089 & 0.065 & 0.208 & 0.207 & 0.190 \\
\hline [ Usia & 0.110 & 0.106 & 0.080 & 0.053 & 0.062 & 0.044 \\
\hline - Lamanya kerja & & -0.115 & -0.127 & 0.055 & 0.057 & 0.049 \\
\hline - Status pernikahan & & 0.025 & 0.049 & 0.137 & 0.135 & 0.151 \\
\hline Dukungan organisasional & & 0.030 & -0.136 & & -0.054 & -0.170 \\
\hline Politik organisasional & & & $-0.275^{\star}$ & & & -0.191 \\
\hline $\mathrm{R}^{2}$ & 0.015 & 0.016 & 0.062 & 0.066 & 0.069 & 0.091 \\
\hline Adjusted $\mathrm{R}^{2}$ & -0.032 & -0.043 & -0.006 & 0.021 & 0.012 & 0.024 \\
\hline & 0.324 & 0.271 & 0.906 & 1.475 & 1.221 & 1.366 \\
\hline$\Delta \mathrm{R}^{2}$ & & & & & & 0.022 \\
\hline
\end{tabular}

${ }^{\star} p<0.05,{ }^{* \star} p<0.01,{ }^{* \star \star} p<0.001$ 
Tabel 9

Analisis Regresi Hirarkikal untuk masing-masing variabel dependen

\begin{tabular}{|c|c|c|}
\hline \multirow[t]{2}{*}{ Nama Variabel } & Politik (I)-Dukungan (II) & Dukungan (I)-Politik (II) \\
\hline & $\Delta \mathbf{R}^{2}$ & $\Delta \mathbf{R}^{2}$ \\
\hline Kepuasan kerja & 0.000 & $0.065^{\star}$ \\
\hline Turnover intent & $0.037^{\star \star *}$ & $0.046^{\star \star *}$ \\
\hline Komitmen afektif & $0.085^{\star \star \star}$ & $0.029^{\star \star \star}$ \\
\hline Komitmen continuance & 0.028 & 0.000 \\
\hline Komitmen normatif & $0.03^{*}$ & $0.011^{*}$ \\
\hline Kinerja & 0.000 & 0.000 \\
\hline $\mathrm{OCB}$ & 0.018 & 0.022 \\
\hline$<0.05,{ }^{* \star} p<0.01,{ }^{* \star *} p<0$. & & \\
\hline
\end{tabular}

